Article

\title{
TrmFO, a Fibronectin-Binding Adhesin of Mycoplasma bovis
}

\author{
Yongpeng Guo ${ }^{1, \dagger}$, Hongmei Zhu ${ }^{1, \dagger}{ }^{+}$Jiayao Wang ${ }^{1}$, Jing Huang ${ }^{1}$, Farhan Anwar Khan ${ }^{1}$, \\ Jingjing Zhang ${ }^{1}$, Aizhen Guo ${ }^{1,2,3}$ and Xi Chen ${ }^{1,2, *}$ \\ 1 College of Veterinary Medicine, Huazhong Agricultural University, Wuhan 430070, China; \\ gyp18771951786@gmail.com (Y.G.); hongmeizhu429@gmail.com (H.Z.); hzauwjy@gmail.com (J.W.); \\ jinghuang@webmail.hzau.edu.cn (J.H.); farhan82@aup.edu.pk (F.A.K.); jjzhang@webmail.hzau.edu.cn (J.Z.); \\ aizhen@mail.hzau.edu.cn (A.G.) \\ 2 The State Key Laboratory of Agricultural Microbiology, Huazhong Agricultural University, \\ Wuhan 430070, China \\ 3 Hubei International Scientific and Technological Cooperation Base of Veterinary Epidemiology, \\ Huazhong Agricultural University, Wuhan 430070, China \\ * Correspondence: chenxi@mail.hzau.edu.cn; Tel.: +86-027-8728-6861 \\ + These authors contributed equally to this work.
}

Received: 16 April 2017; Accepted: 2 August 2017; Published: 9 August 2017

\begin{abstract}
Mycoplasma bovis is an important pathogenic mycoplasma, causing the cattle industry serious economic losses. Adhesion is a crucial step in the mycoplasmas' infection and colonization process; fibronectin (Fn), an extracellular matrix glycoprotein, is a molecular bridge between the bacterial adhesins and host cell receptors. The present study was designed to characterize the Fn-binding ability of methylenetetrahydrofolate-tRNA-(uracil-5-)-methyltransferase (TrmFO) and its role in $M$. bovis cytoadherence. The trmFO (MBOV_RS00785) gene was cloned and expressed in E. coli BL21, and polyclonal antibodies against the recombinant TrmFO (rTrmFO) were raised in rabbits. Immunoblotting demonstrated that TrmFO was an immunogenic component, and the TrmFO expression was conserved in different $M$. bovis isolates. The mycoplasmacidal assay further showed that in the presence of complement, rabbit anti-recombinant TrmFO serum exhibited remarkable mycoplasmacidal efficacy. TrmFO was detected in both the M. bovis membrane and cytoplasm. By ligand dot blot and enzyme-linked immunosorbent assay (ELISA) binding assay, we found that rTrmFO bound Fn in a dose-dependent manner. Immunostaining visualized by confocal laser scanning microscopy showed that rTrmFO had capacity to adhere to the embryonic bovine lung (EBL) cells. In addition, the adhesion of $M$. bovis and rTrmFO to EBL cells could be inhibited by anti-rTrmFO antibodies. To the best of our knowledge, this is the first report to characterize the Fn-binding ability of TrmFO and its role in the bacterial adhesion to host cells.
\end{abstract}

Keywords: Mycoplasma bovis; TrmFO; fibronectin; adhesion

\section{Introduction}

Mycoplasma bovis is the causative agent of bovine mycoplasmosis which results in pneumonia, mastitis, arthritis and genital disorders [1,2]. M. bovis was first isolated from the milk of cattle with mastitis by Hale in 1961 in the USA [3], and this pathogen has resulted in enormous economic losses to the cattle industry worldwide. In 2008, during an outbreak of $M$. bovis pneumonia and arthritis in China, M. bovis strain Hubei-1 and HB0801 were isolated, and the complete genome of both strains has been sequenced [4,5]. Due to the lack of genetic tools and other advanced research techniques, knowledge concerning the pathogenesis of $M$. bovis is relatively scarce, seriously hampering development of potential therapeutic and prophylactic measures [3]. 
Mycoplasmas evolved from Gram-positive bacteria through a process of regressive evolution, resulting in limitation of their biosynthesis capacities [6]. Most mycoplasmas display strict host and tissue specificities [7]. Adherence of mycoplasmas to host cells is a critical step in the initial phase of infection and an absolute requirement for successful colonization. Adhesins serve as vital virulence attributes in mycoplasmas, and decline of adhesion ability generally attenuates the bacteria [8]. Several adhesion proteins have been identified in $M$. bovis, including a $32 \mathrm{kDa}$ membrane-localized protein P26 [9], a plasminogen binding enzyme $\alpha$-enolase [10], NADH oxidase [11] and several variable surface lipoproteins (VspA, VspB, VspE, VspF and VpmaX) [12,13]. Identification and characterization of other adhesins will facilitate a better understanding of interactions between M. bovis and host cells.

Fibronectin (Fn), a multifunctional extracellular matrix glycoprotein, exists in soluble and matrix forms in diverse body fluids and tissues, and the binding of Fn is associated with bacterial colonization, bacteria-host interactions and virulence behavior [14,15]. It is suggested that Fn-binding proteins (FnBPs) can promote bacterial adhesion to host cells via a sandwich model in which Fn acts as a molecular bridge between surface exposed FnBPs and integrins on host cells $[14,16]$. Several FnBPs have been identified in mycoplasmas, including elongation factor $\mathrm{Tu}(\mathrm{EF}-\mathrm{Tu})$, glyceraldehyde-3-phosphate dehydrogenase (GAPDH) and pyruvate dehydrogenase A-C (PDH A-C) in Mycoplasma pneumoniae [17,18], Mhp182 and Mhp271 in Mycoplasma hyopneumoniae [19,20], enolase in Mycoplasma synoviae [21], PlpA and Hlp3 in Mycoplasma gallisepticum [22], and cytoadhesive lipoprotein $\mathrm{T}$ (LppT) in Mycoplasma conjunctivae [23]. These findings highlight the possibility that there may also be FnBPs in M. bovis, which might contribute to M. bovis infection in and persistence on host cells.

Recently, our laboratory developed an effective attenuated $M$. bovis vaccine through passage of M. bovis HB0801 150 times in vitro [24]. Although the underlying mechanisms of attenuation of the M. bovis-150 strain (CCTCC No.: M2011102) remain unclear, it can be speculated that the down-regulation and the absence of some virulence factors could be responsible for the attenuation. Methylenetetrahydrofolate-tRNA-(uracil-5-)-methyltransferase (TrmFO) is a conserved flavin dinucleotide (FAD) binding protein, which has been identified as the member of tRNA modification enzymes responsible for the folate-dependent $\mathrm{m}^{5} \mathrm{U}-54$ biosynthesis [25]. Using an iTRAQ-based quantitative proteomic analysis, we found that expression of TrmFO was down-regulated in the attenuated M. bovis-150 strain compared to the virulent strain M. bovis HB0801 (unpublished data). Among these down-regulated proteins in the attenuated M. bovis-150 strain, NADH oxidase and variable lipoprotein VspX have been reported to contribute to $M$. bovis adhesion to host cells $[11,13]$. In the light of this, the aim of current study was to characterize the moonlight function of TrmFO in the pathogenesis of M. bovis.

\section{Results}

\subsection{Bioinformatics Analysis}

In M. bovis HB0801, the 1284-bp ORF of trmFO (MBOV_RS00785) gene encoded a 427-amino-acid protein with a molecular weight of $48.8 \mathrm{kDa}$ and isoelectric point of 6.43. M. bovis HB0801 TrmFO shared more than $98 \%$ amino acid level identity with TrmFO from other sequenced M. bovis strains, while it exhibited $\leq 80 \%$ homology with TrmFO from other mycoplasmal species (Table 1). TrmFO contained no conventional signal peptide or transmembrane domain. TrmFO was predicted to be a cytoplasmic protein by subcellular localization predictor (CELLO). 
Table 1. Amino acid sequence identity of M. bovis HB0801 methylenetetrahydrofolate-tRNA(uracil-5-)-methyltransferase (TrmFO) with those of other mycoplasmas.

\begin{tabular}{ccc}
\hline Species & Identity & NCBI Protein ID \\
\hline Mycoplasma bovis Hubei-1 & $100 \%$ & AEI89864.1 \\
Mycoplasma bovis CQ-W70 & $100 \%$ & AIA33742.1 \\
Mycoplasma bovis PG45 & $98 \%$ & ADR24753.1 \\
Mycoplasma agalactiae PG2 & $80 \%$ & CAL58845.1 \\
Mycoplasma putrefaciens KS1 & $56 \%$ & AEM68895.1 \\
Mycoplasma sp. HU0214 & $55 \%$ & KNG79513.1 \\
Mycoplasma yeastsii GM274B & $54 \%$ & AJM71909.1 \\
Mycoplasma capricolum subsp. capricolum 14232 & $48 \%$ & KEZ18460.1 \\
Mycoplasma mycoides subsp. capri str. GM12 & $48 \%$ & ACU78480.1 \\
\hline
\end{tabular}

NCBI, the National Center for Biotechnology Information.

\subsection{Expression and Purification of Recombinant TrmFO (rTrmFO)}

The full-length trmFO was amplified from M. bovis HB0801 and cloned into plasmid pET-30a (+) to facilitate the expression and purification of recombinant TrmFO (rTrmFO). After induction by $0.8 \mathrm{mM}$ IPTG, the overexpression of rTrmFO in E. coli BL21 resulted in a protein with apparent molecular size of $54 \mathrm{kDa}$ (Figure 1A). The observed increase in the molecular size of rTrmFO over the native TrmFO was attributed to its N-terminal His-tag. Purified rTrmFO was recognized by mouse anti-His tag antibody on immunoblotting analysis (Figure 1B).

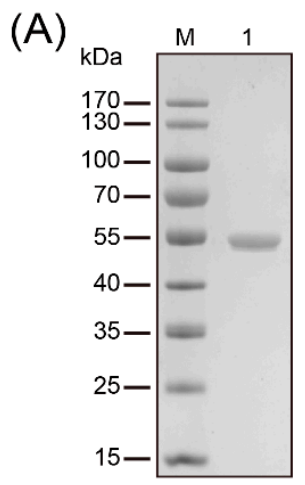

(B)

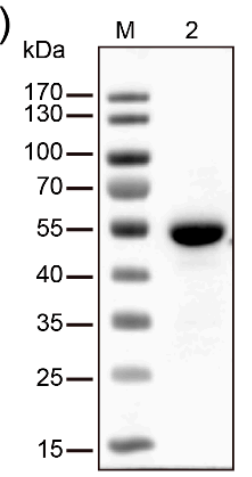

Figure 1. Purification and identification of recombinant methylenetetrahydrofolate-tRNA(uracil-5-)-methyltransferase (TrmFO). (A) SDS-PAGE analysis confirmed the purity of the recombinant TrmFO (rTrmFO). M: Molecular weight marker; Lane 1: Purified rTrmFO. (B) Immunoblotting analysis of the rTrmFO using mouse anti-His tag antibodies. M: Molecular weight marker; Lane 2: rTrmFO.

\subsection{Immunogenicity Analysis of rTrmFO}

M. bovis-positive sera recognized the $\mathrm{rTrmFO}$, whereas $M$. bovis-negative serum did not display reactivity with the recombinant protein on western blotting (Figure 2). The results suggested that $M$. bovis-infected cattle generated specific antibodies against TrmFO, thereby indicating that the TrmFO was an immunogenic component in M. bovis. 


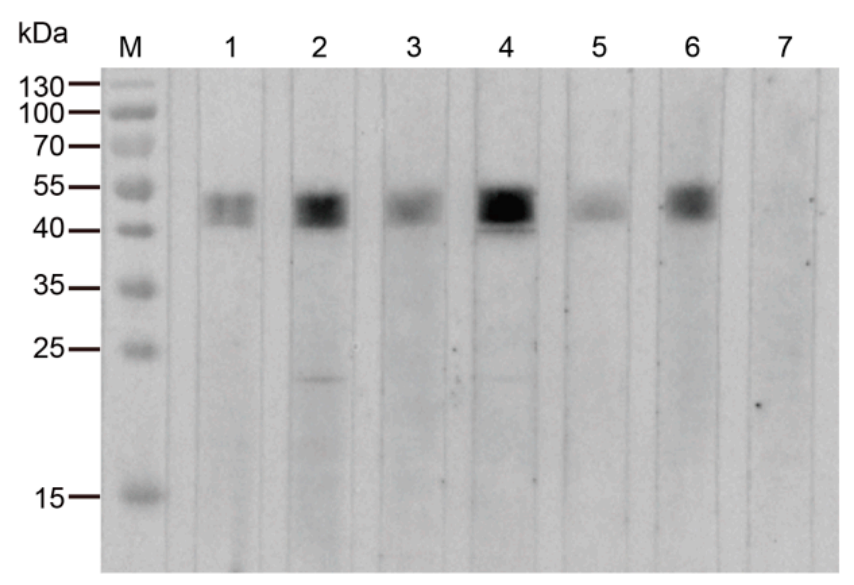

Figure 2. Immunoblotting analysis of the purified rTrmFO with individual M. bovis-positive and M. bovis-negative sera. M: Molecular weight marker; Lanes 1 to 3: Individual positive sera from experimentally $M$. bovis infected cattle; Lanes 4 to 6 : Individual positive sera from naturally M. bovis-infected cattle; Lane 7: $M$. bovis-negative serum.

\subsection{Expression of TrmFO in Different M. bovis Isolates}

Eight $M$. bovis strains originating from different districts and lesions were analyzed. Rabbit anti-rTrmFO polyclonal antibodies strongly reacted with a $49 \mathrm{kDa}$ protein corresponding to TrmFO in all tested M. bovis strains (Figure 3).

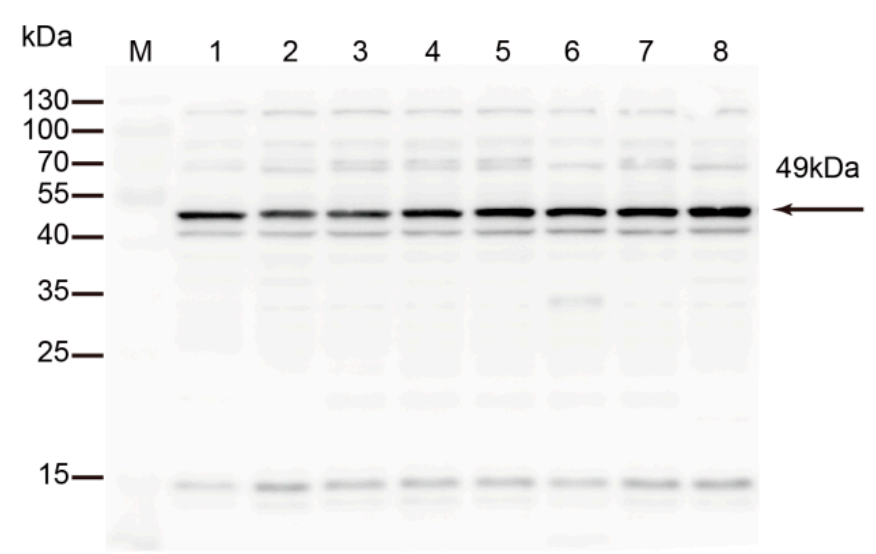

Figure 3. Detection of TrmFO in different strains of $M$. bovis. Western blotting analysis was conducted with $20 \mu \mathrm{g}$ of whole cell proteins in each lane. M: Molecular weight marker; Lanes 1 to 8: M. bovis strain HB0801, PG45, XM, JXXY, BZ, NNH, WX and YC, respectively.

\subsection{Mycoplasmacidal Activity of Rabbit Anti-rTrmFO Serum}

Rabbit anti-rTrmFO serum exhibited strong mycoplasmacidal activity mediated by a complement system. Compared to the rabbit pre-immune serum, incubation of the anti-rTrmFO serum with $M$. bovis HB0801 in the presence of the complement resulted in effective killing of the bacteria (Figure 4). 


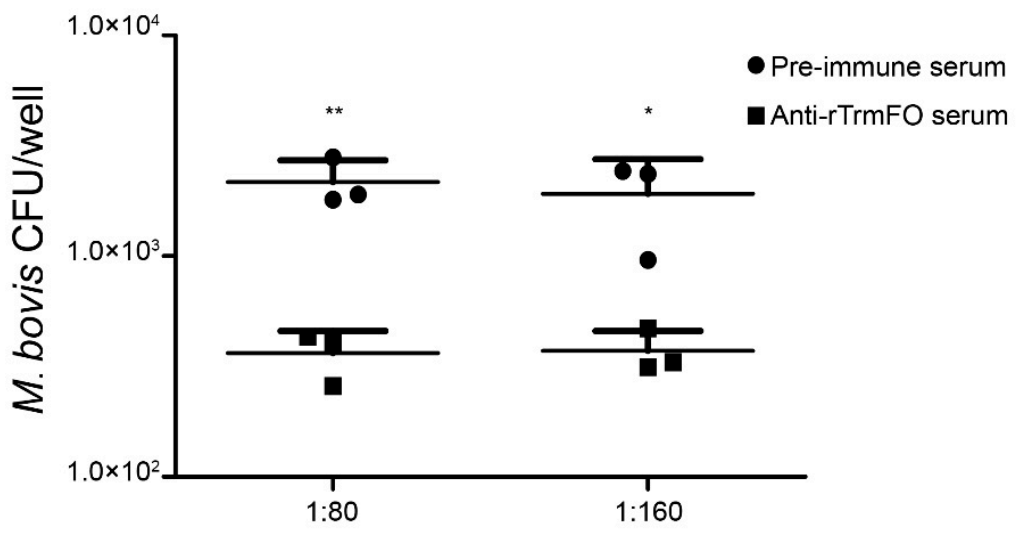

Figure 4. Mycoplasmacidal activity of rabbit anti-rTrmFO serum. M. bovis HB0801 was incubated with rabbit pre-immune or anti-rTrmFO serum (diluted 1:80 and 1:160) in the presence of complement. Data represent the mean \pm SEM from three separate experiments. ${ }^{*}$ and ${ }^{* *}$ represent $p<0.05$ and $p<0.01$, respectively.

\subsection{Subcellular Localization of TrmFO in M. bovis}

TrmFO was detected in the membrane, cytoplasm, and whole cell proteins of M. bovis (Figure 5A), indicating that TrmFO was localized in both $M$. bovis cell membrane and cytoplasm. The control monoclonal antibodies against $\mathrm{rVspX}$ only reacted with the membrane and whole cell proteins, confirming that the membrane and cytoplasm protein fractions were free of cross contamination.

(A)

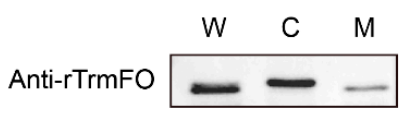

Anti-rVspX
(B)

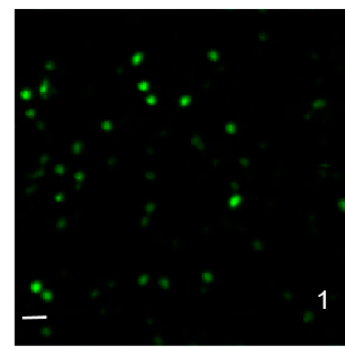

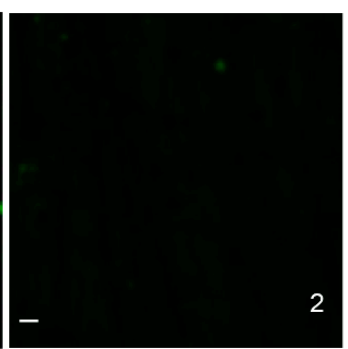

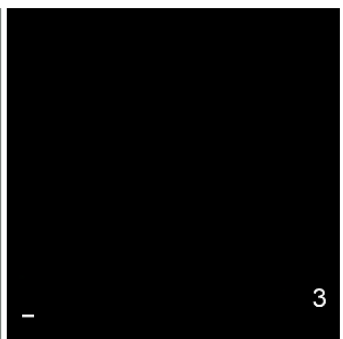

Figure 5. Subcellular localization of TrmFO in M. bovis. (A) Western blotting analysis. W: whole cell proteins; C: cytoplasmic proteins; M: membrane proteins. (B) Immunofluorescence assay. B1: M. bovis cells were incubated with rabbit anti-rTrmFO serum. B2: M. bovis cells were incubated with rabbit pre-immune serum. B3: M. bovis cells were incubated with PBS. Bars, $2 \mu \mathrm{m}$.

In the immunofluorescence assay (IFA) with rabbit anti-rTrmFO antibodies, staining of M. bovis with fluorescein isothiocyanate was observed (Figure 5B1), whereas IFA with pre-immune serum exhibited little staining (Figure 5B2) and with PBS no signal (Figure 5B3), suggesting that TrmFO was membrane-localized.

\subsection{Fibronectin (Fn)-Binding Ability of rTrmFO}

To determine whether $M$. bovis TrmFO was a Fn binding protein, ligand dot blot and an enzyme-linked immunosorbent assay (ELISA) binding assay were performed. In the ligand dot blot assay, TrmFO exhibited Fn-binding activity (Figure 6A, lane 1), while no interaction was observed between Fn and bovine serum albumin (BSA) under similar conditions (Figure 6A, lane 2). It was further confirmed by ELISA that immobilized rTrmFO bound to Fn in a dose-dependent manner (Figure 6B). 

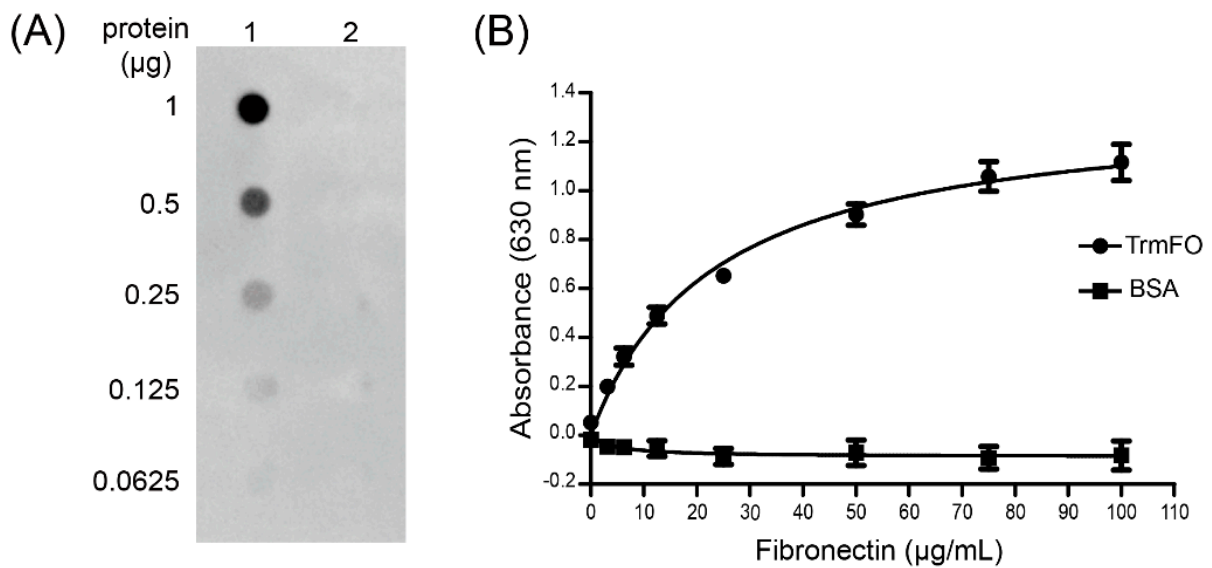

Figure 6. Characterization of the fibronectin (Fn)-binding ability of rTrmFO. (A) Ligand dot blot assay demonstrated the Fn-binding ability of rTrmFO. 1: rTrmFO; 2: bovine serum albumin (BSA). (B) Binding of Fn to immobilized rTrmFO in microplate. All data represent the mean $\pm \mathrm{SEM}$ of triplicate readings from three independent experiments $(n=9)$.

\subsection{Direct Adhesion of rTrmFO to EBL Cells and Adhesion Inhibition}

The adhesion of rTrmFO to EBL cells was determined by laser scanning confocal microscopy. rTrmFO was shown to be capable of adhering to the fixed EBL cells (Figure 7A). After pre-incubation with rabbit anti-rTrmFO serum, rTrmFO adherence to EBL cells was significantly inhibited (Figure 7B). The PBS control showed no adherence to EBL cells (Figure 7C). M. bovis adhesion to EBL cells could be significantly inhibited by rabbit anti-rTrmFO serum (Figure 8).

(A)
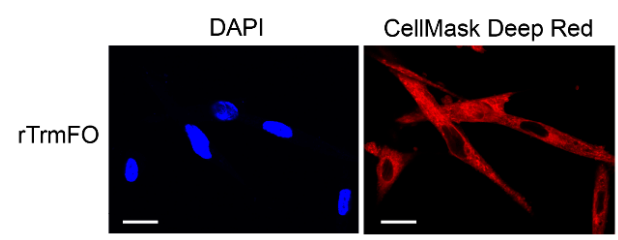

Alexa-488
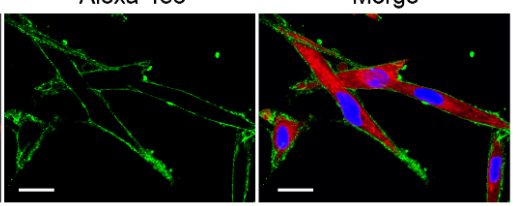

(B)

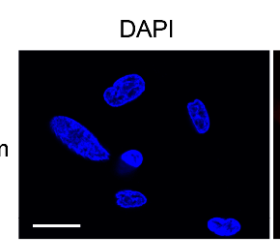

CellMask Deep Red

Alexa-488

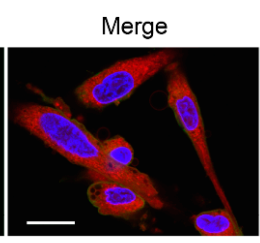

(C)

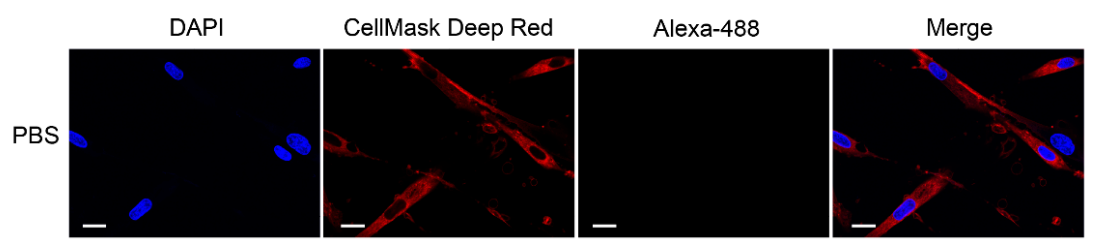

Figure 7. Confocal laser scanning microscopy depicting rTrmFO adhesion to EBL cells and adhesion inhibition of rabbit anti-rTrmFO serum. EBL cells were fixed, incubated with rTrmFO and immunostained with rabbit anti-rTrmFO polyclonal antibodies and donkey anti-rabbit IgG (whole molecule)-Alexa 488. Cell nuclei and membranes were labeled with 4',6-diamidino-2-phenylindole (DAPI) and CellMask Deep Red, respectively. (A) The rTrmFO exhibited adhesion ability to EBL cells. (B) The rTrmFO was pre-incubated with anti-rTrmFO serum, then this mixture was added to the fixed cells. The adherence process was significantly inhibited by rabbit anti-rTrmFO antibodies. (C) PBS was used as a negative control. Bars, $20 \mu \mathrm{m}$. 


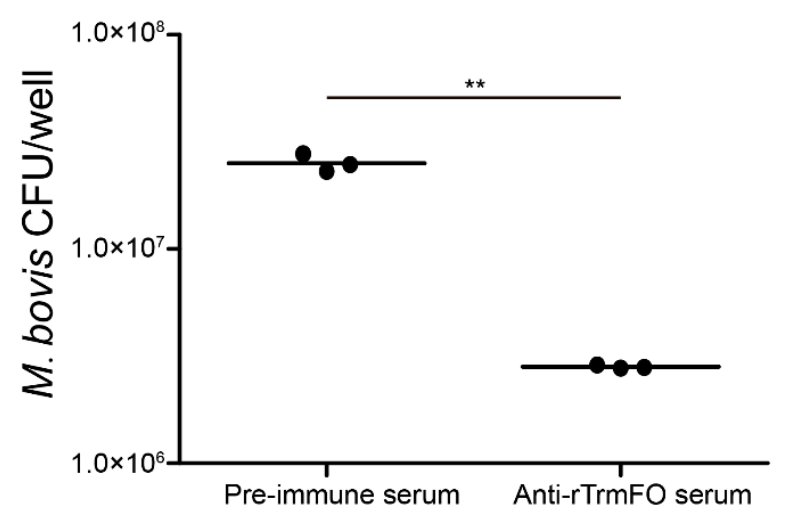

Figure 8. The adhesion of M. bovis to EBL cells was inhibited by rabbit anti-rTrmFO serum. M. bovis was incubated with rabbit pre-immune or anti-rTrmFO serum (diluted 1:50 in PBS). Data represent the mean \pm SEM from three separate experiments. ${ }^{* *}$ represents $p<0.01$.

\section{Discussion}

By means of 150 passages of the wild-type M. bovis strain HB0801, we recently created an avirulent $M$. bovis-150, which was confirmed to exhibit protective ability against $M$. bovis-related pneumonia in calves [24]. TrmFO, a FAD-binding protein responsible for catalyzing the site-specific formation of 5 -methyluridine in position 54 ( $\left.\mathrm{m}^{5} \mathrm{U} 54\right)$ of tRNA in bacteria, has been identified to be down-regulated in the attenuated M. bovis-150 strain. Homology analysis indicated that TrmFO was identical at amino acid level among sequenced $M$. bovis strains and other mycoplasmas. Additionally, the recombinant TrmFO could be specifically recognized by sera of naturally and experimentally M. bovis-infected cattle. The antigenic conservation of TrmFO was also confirmed by immunoblotting, in which rabbit anti-rTrmFO antibodies strongly reacted with a $49 \mathrm{kDa}$ protein corresponding to TrmFO in all M. bovis isolates tested. In the mycoplasmacidal assay, we found that rabbit anti-rTrmFO serum displayed effective M. bovis killing capacity in the presence of complement. Currently, great efforts have been made in exploiting novel immunodominant antigens of M. bovis, and several important antigenic proteins have been found including variable surface proteins (Vsp), lipoprotein P48, Hsp60, MbovP579, lipase A (MilA), PDHB, and GAPDH [12,26-31]. Among these, MbovP579, PDHB and MilA have been applied as serological diagnostic markers of $M$. bovis infection. Meanwhile, a subunit vaccine based on GAPDH has been shown to induce high IgG1 titers but failed to protect cattle exposed to $M$. bovis [32]. The results of the current study suggested that TrmFO, as a highly conserved antigen within the $M$. bovis cluster, could be a promising candidate for developing effective DNA or protein subunit vaccines. However, further studies in vivo are needed to determine whether TrmFO can elicit a protective immune response against $M$. bovis infection.

Neither transmembrane domains for surface anchoring nor classical secretory signal peptides were found on $M$. bovis TrmFO. However, by western blotting, TrmFO was detected in both the cell membrane and cytoplasm. The surface localization of M. bovis TrmFO was further confirmed by immunofluorescence assay. The dual cellular distribution of TrmFO suggested that the protein may carry out a moonlighting function in M. bovis. A growing number of cytoplasmic proteins have been shown to actively participate in bacterial adhesion and colonization processes when expressed on the cell surface [33]. GAPDH and enolase are two widely studied bacterial glycolytic enzymes with adhesion capacity. GAPDH has been shown to play an important role in bacterial selective adhesion to host components, including epithelial cells, extracellular matrix proteins, cytoskeleton proteins, and so on [34]. Enolase has been characterized as a plasminogen receptor in Mycobacterium tuberculosis [35], Streptococcus pneumoniae [36], Bacillus anthracis [37], and pathogenic mycoplasmas [10,38-40], facilitating the proteolytic plasmin activity of these pathogens, which potentially promotes their tissue invasion and dissemination in hosts. Apart from glycolysis enzymes, there are also proteins involved in other metabolic pathways that have been 
found to be translocated to cell membrane and contribute to bacterial virulence. NADH oxidase is an adhesion-related factor in Streptococcus pneumoniae, and immunization of mice with recombinant $\mathrm{NADH}$ oxidase has been shown to induce a protective immune response against $S$. pneumoniae [41]. In M. pneumoniae, EF-Tu was surface-exposed and displayed fibronectin binding ability [17]. Similar to these moonlighting proteins, we have provided evidence in the current study that TrmFO is a binding partner of bovine fibronectin and serves as an adhesin in M. bovis.

In the absence of a rigid cell wall, the pathogenicity of mycoplasmas is highly dependent on the cytoplasmic membrane which is in direct contact with host cells during attachment [42]. Fibronectin is a glycoprotein widely present in the extracellular matrix and body fluids, which contain binding sites for various extracellular molecules, including fibrin, gelatin, heparin and adhesion receptors [14]. In this context, capture of fibronectin via surface-anchored adhesins is a common strategy for bacteria to strengthen their adhesion to and invasion of host cells [16]. In terms of mycoplasma species, dose-dependent Fn recognition was first observed in M. penetrans [43], followed by M. pneumoniae, in which the carboxyl region of EF-Tu interacted with Fn [44]. M. conjunctivae LppT was shown to contain an RGD (Arg-Gly-Asp) motif that is a specific binding site for both Fn and beta heparins of eukaryotic host cells [23]. Using ligand dot blot and ELISA binding assay, we demonstrated that M. bovis TrmFO possessed fibronectin binding ability. Work is currently in progress to identify amino acid sequence motifs that correspond to the fibronectin-binding property of TrmFO. More importantly, TrmFO was found to be a novel adhesin in M. bovis, based on the direct adhesion and inhibition assay in which rTrmFO was observed to adhere to EBL cells and the adhesion was inhibited by anti-rTrmFO polyclonal antibodies. Furthermore, the adhesion of $M$. bovis to EBL cells could also be reduced when the bacteria were pre-incubated with anti-rTrmFO serum. Comparative genomics of $M$. bovis strains reveals a 14.2-kb deleted region covering 14 genes in the attenuated M. bovis-150 strain [45]. However, the production of $\mathrm{H}_{2} \mathrm{O}_{2}$, a significant virulence related factor in mycoplasma species, was not affected by the mutations specific to the genes in the $14.2-\mathrm{kb}$ deleted region. In fact, the down-regulation of virulence factors like TrmFO should be partly responsible for the attenuation of the M. bovis-150 strain. As far as we know, this is the first report to characterize the fibronectin binding property of bacterial TrmFO. In addition, we have shown that the protein exerts an additional function on $M$. bovis adhesion to EBL cells. The findings suggest that TrmFO is of great importance in the M. bovis-host cell interaction. The knowledge of the interplay among M. bovis adhesins, fibronectin and host cell receptors will provide a further piece in the puzzle of bacterial invasion and persistence in different bovine cell types.

\section{Materials and Methods}

\subsection{Ethics Statement}

The animal experiment protocols in this study were in strict accordance with the Hubei Regulations for the Administration of Affairs Concerning Experimental Animals. Animal experiments were approved by the Hubei Province Science and Technology Department, which is responsible for experimental animal ethics. All experiments were supervised by the Scientific Ethical Committee for Experimental Animals of Huazhong Agricultural University, Wuhan, China (Permit Number: HZAURAB-2015-006).

\subsection{Bioinformatics Analysis}

Amino acid identity matches were conducted with BLASTP [46]. SignalP 4.1 Server was used to predict the presence of signal peptide [47]. Prediction of transmembrane helices in TrmFO was performed with TMHMM Server V. 2.0 [48]. CELLO was employed to predict protein subcellular localization [49]. 


\subsection{Bacterial Strains, Cultivation Conditions and Cell Line}

M. bovis strain HB0801 was isolated from a calf lung with pneumonia and stored at the China Center for Type Culture Collection (CCTCC; M2010040). The strain was cultivated in an atmosphere of $37^{\circ} \mathrm{C}, 5 \% \mathrm{CO}_{2}$ on a pleuropneumonia-like organism (PPLO) agar plate or in PPLO broth containing $2.1 \%(w / v)$ PPLO broth, $0.5 \%(w / v)$ yeast extract, $0.1 \%(w / v)$ sodium pyruvate, $0.001 \%(w / v)$ phenol red, 20\% donor equine serum (Hyclone, South Logan, UT, USA), and 400,000 IU/L penicillin-G.

Escherichia coli strains DH5 $\alpha$ and BL21 (TransGen Biotech, Beijing, China) were cultured at $37^{\circ} \mathrm{C}$ on Luria-Bertani (LB) agar plates or in LB broth supplemented with $30 \mu \mathrm{g}$ kanamycin $/ \mathrm{mL}$ as selection needed. E. coli DH5 $\alpha$ was used as the host cell for DNA manipulation, while E. coli BL21 was used for the expression of recombinant protein. The embryonic bovine lung (EBL) cells, certified to be free of mycoplasma contamination, were cultured in MEM supplemented with $15 \%$ fetal bovine serum (Gibco, Sydney, Australia), $100 \mathrm{IU}$ penicillin/mL, and $100 \mu \mathrm{g}$ streptomycin/mL.

\subsection{Cloning, Expression and Purification of rTrmFO}

M. bovis HB0801 chromosomal DNA was used as template for amplification of the trmFO gene. TGA is a universal termination codon but it encodes tryptophan in mycoplasmas. When cloning a mycoplasmal gene in the E. coli expression system, the presence of TGA codon can lead to the early termination of gene translation. In this study, the TGA codon is not found in the coding sequence of the trmFO gene. Specific primers for amplifying trmFO were designed with Oligo 7 software (Molecular Biology Insights, West Cascade, CO, USA) as follows: F5'-GGCGGTACCATGAAAAAAATAAGAGTTATTG- ${ }^{\prime}$ and R5' $^{\prime}$-CGGGGATCCCTATAAATTTTGCTT AATAAAC- $3^{\prime}$ (underlined sequences represent $K p n I$ and BamHI restriction sites, respectively). The PCR product was cloned into pET-30a (+) vector (Novagen, Madison, WI, USA). His-tagged TrmFO was expressed in E. coli BL21 and purified by Ni-NTA columns affinity chromatography under native conditions according to the manufacturer's instructions (GE Healthcare, Boston, MA, USA). The purified rTrmFO was analyzed by SDS-PAGE and by western blotting using mouse anti-His tag antibodies (Cell Signaling Technology, Danvers, MA, USA). Protein concentration was quantified using a BCA protein assay kit (Thermo Fisher Scientific, Waltham, MA, USA).

\subsection{Preparation of Polyclonal Antibodies Against rTrmFO}

Antiserum to rTrmFO was raised in New Zealand White rabbits by subcutaneous immunization with $1 \mathrm{mg}$ of purified rTrmFO emulsified in Freund's complete adjuvant (only for the first immunization) or Freund's incomplete adjuvant (Sigma, St Louis, MO, USA). The immunization was conducted three times at 2-week intervals. The antibody titers were measured by ELISA. Briefly, the 96-well plates were coated with purified $\mathrm{rTrmFO}(100 \mathrm{ng} /$ well $)$ at $4{ }^{\circ} \mathrm{C}$ overnight. After being washed three times with PBST, unoccupied sites were blocked with $5 \%$ skim milk in PBST for $1 \mathrm{~h}$ at $37^{\circ} \mathrm{C}$. The two-fold serial dilution (from 1:1 $\times 100$ to 1:2 $22 \times 100$ ) of rabbit serum anti-rTrmFO and pre-immune serum were added to wells. Then, bound antibodies were detected by incubation with horseradish peroxidase (HRP)-labeled goat anti-rabbit IgG (diluted 1:4000) for $1 \mathrm{~h}$. Rabbits were sacrificed via cardiac bleeding to collect positive antiserum 10 days after the third immunization. The antibody titer to $\mathrm{rTrmFO}$ was 1:2 $2^{16} \times 100$ (positive serum OD: negative serum OD $\geq 2.1$. The polyclonal antibodies against $r$ TrmFO were purified using a HiTrap Protein G affinity column (GE Healthcare, Boston, MA, USA).

\subsection{Immunoblotting Analysis}

Immunoblotting was performed to analyze whether TrmFO played an immunogenic role using $M$. bovis positive sera. Purified rTrmFO was electrophoretically separated on a $12 \%$ SDS-PAGE gel and then transferred onto the PVDF membrane (Millipore Corp, Billerica, MA, USA). The membrane was blocked with $5 \%$ skim milk in TBS at $4{ }^{\circ} \mathrm{C}$ overnight. The blots were washed with TBST $(1 \mathrm{~mL} / \mathrm{L}$ Tween-20, $100 \mathrm{mM}$ Tris-Cl, $9 \mathrm{~g} / \mathrm{L} \mathrm{NaCl}, \mathrm{pH}$ 7.5) and incubated with bovine sera (diluted 1:100 in 
TBST, 6 positive and 1 negative M. bovis sera) at room temperature for $1 \mathrm{~h}$. Later, bound antibodies were detected by incubation for $1 \mathrm{~h}$ with horseradish peroxidase (HRP)-labeled goat anti-bovine IgG (SouthernBiotech, Birmingham, AL, USA) (diluted 1:4000 in TBST). Color development was performed using Chemiluminescent Substrate (Thermo, Fisher Scientific, Waltham, MA, USA). Then the signals were detected on the Image DNR MF-ChemiBIS (NDR, Jerusalem, Israel).

To assess the expression of TrmFO in different $M$. bovis isolates, whole cell proteins of eight $M$. bovis strains (Table S1) were transferred to the PVDF membrane and probed with rabbit anti-rTrmFO polyclonal antibodies (diluted 1:2000). Subsequently, the membrane was washed and incubated with HRP-labeled goat anti-rabbit IgG (diluted 1:4000). Immunoreactive bands were developed using Chemiluminescent Substrate.

\subsection{Complement Dependent Mycoplasmacidal Assay}

Rabbit pre-immune serum and anti-rTrmFO serum were inactivated at $56{ }^{\circ} \mathrm{C}$ for $30 \mathrm{~min}$ and used to test for bactericidal activity against $M$. bovis $\mathrm{HB} 0801$ by a complement-mediated bactericidal assay as previously described with some modifications [22]. Briefly, $50 \mu \mathrm{L}$ of rabbit pre-immune serum or antiserum was added to the wells of a 96-well plate; then, $30 \mu \mathrm{L}$ of bacterial suspension $\left(\sim 10^{5}\right.$ colony-forming unit $\left./ \mathrm{mL}\right)$ in Dulbecco's PBS containing calcium, magnesium, and $0.1 \%$ gelatin (DPBSG) and $20 \mu \mathrm{L}$ of diluted complement (1:10 in DPBSG) were added. Following incubation at $37^{\circ} \mathrm{C}$ for $1 \mathrm{~h}$, the mixture was tenfold serially diluted in PPLO medium and plated onto PPLO agar plates. The plates were incubated at $37^{\circ} \mathrm{C}$ for $48 \mathrm{~h}$ with $5 \% \mathrm{CO}_{2}$, and colonies were counted under a microscope. Three independent experiments were conducted in triplicate.

\subsection{Subcellular Localization of M. bovis TrmFO}

To identify the subcellular distribution of $M$. bovis TrmFO, membrane and cytoplasmic proteins of $M$. bovis HB0801 were extracted by glycerol-osmotic lysis with a slight modification [50]. Briefly, $1 \mathrm{~L}$ of mycoplasmas in mid-log phase was harvested by centrifugation at $12,000 \times g$ for $15 \mathrm{~min}$. Cell pellets were washed with $0.25 \mathrm{M} \mathrm{NaCl}$ three times prior to resuspension in $5 \mathrm{~mL}$ of $2 \mathrm{M}$ glycerol. Cell suspensions were then lysed by rapid transference into 50 volumes of preheated, deionized water and incubated at $37^{\circ} \mathrm{C}$ for $15 \mathrm{~min}$ with shaking. Membrane fractions were collected by centrifugation at $60,000 \times \mathrm{g}$ for $45 \mathrm{~min}$, and sequentially washed in deionized water, followed by $0.25 \mathrm{M} \mathrm{NaCl}$, and again deionized water. Membranes were further purified by centrifugation through $30-60 \%$ continuous sucrose gradient at $160,000 \times \mathrm{g}$ for $4 \mathrm{~h}$ at $4{ }^{\circ} \mathrm{C}$ and collected by a syringe. Cytoplasmic fractions were concentrated by passing an ultrafiltration column (Millipore Corp, Billerica, MA, USA). Proteins were quantified with a BCA Protein Assay Kit. Twenty micrograms of total, membrane and cytoplasmic proteins were separated by $12 \%$ SDS-PAGE and transferred onto PVDF membranes. After being washed three times with TBST, unoccupied sites were blocked with $5 \%$ skim milk in TBST for $1 \mathrm{~h}$ at $37^{\circ} \mathrm{C}$, followed by incubation with rabbit anti-rTrmFO polyclonal antibodies (diluted 1:500 in TBST) at $4{ }^{\circ} \mathrm{C}$ overnight. HRP-labeled goat anti-rabbit IgG were used as secondary antibodies (SouthernBiotech, Birmingham, AL, USA) (diluted 1:4000 in TBST). To test possible cross-contamination between the membrane and cytoplasmic proteins, monoclonal antibodies against VspX (membrane protein, self-made) (diluted 1:2000 in TBST) were used [13].

For the immunofluorescence assay, $M$. bovis was cultured in PPLO broth medium to log-phase and washed three times with PBS. The intact $M$. bovis cells $\left(\sim 10^{10} \mathrm{CFU}\right)$ were incubated at $37^{\circ} \mathrm{C}$ for $1.5 \mathrm{~h}$ with rabbit anti-rTrmFO serum (1:100 dilution in PBS), pre-immune serum (1:100) or PBS. Cells were washed with PBS three times, and the samples were incubated with donkey anti-rabbit IgG (whole molecule)-Alexa 488 (AntGene, Wuhan, Hubei, China) diluted 1:300 in PBS at $37^{\circ} \mathrm{C}$ for $1 \mathrm{~h}$. Following five washes with PBS, the cells were dispersed in $300 \mu \mathrm{L}$ of PBS and visualized under a fluorescence microscope (ZEISS, Oberkochen, Germany). 


\subsection{Fibronectin-Binding Assays}

Ligand dot blot and ELISA binding assay were conducted to characterize the binding ability of rTrmFO to bovine Fn. A dot blot binding assay using a Bio-Dot microfiltration apparatus (Bio-Rad, Hercules, CA, USA) was performed as previously described by Jenkins et al. with some modifications [51]. Purified rTrmFO or BSA was twofold serially diluted from a concentration of $10 \mu \mathrm{g} / \mathrm{mL}$ to $0.625 \mu \mathrm{g} / \mathrm{mL}$. Following this, $100 \mu \mathrm{L}$ of proteins were spotted onto a nitrocellulose membrane (Millipore Corp, Billerica, MA, USA). The membrane was removed from the microfiltration apparatus and washed with TBST three times prior to being blocked with $5 \%$ skim milk in TBST at room temperature for $4 \mathrm{~h}$. After being washed three times in TBST, the blot was exposed to $10 \mu \mathrm{g}$ bovine Fn/mL (Millipore Corp, Billerica, MA, USA) diluted in $1 \%$ skim milk-TBST at $4{ }^{\circ} \mathrm{C}$ overnight. After washing, the membrane was incubated with rabbit anti-bovine Fn IgG (Millipore Corp, Temecula, CA, USA) at a dilution of 1:3000 in 1\% skim milk-TBST for $1 \mathrm{~h}$, followed with goat anti-rabbit IgG-HRP (diluted 1:4000 in TBST). The membrane was incubated with Chemiluminescent Substrate, then the signals were detected on the Image DNR MF-ChemiBIS.

For the ELISA binding assay, 96-well plates were coated with purified rTrmFO (500 ng/well) in carbonate coating buffer $\left(18 \mathrm{mM} \mathrm{NaHCO}_{3}, 27 \mathrm{mM} \mathrm{Na}_{2} \mathrm{CO}_{3}, \mathrm{pH} 9.6\right)$. After incubation at $4{ }^{\circ} \mathrm{C}$ overnight, unoccupied sites were blocked with $5 \%$ skim milk in PBST for $1 \mathrm{~h}$ at $37^{\circ} \mathrm{C}$. After being washed five times with PBST, wells were incubated with varying concentrations of bovine Fn (1.562, $3.125,6.25,12.5,25,50,75$ and $100 \mu \mathrm{g} / \mathrm{mL}$ in $1 \%$ skim milk-PBS) at $37^{\circ} \mathrm{C}$ for $1.5 \mathrm{~h}$. Bound Fn was detected by the addition of rabbit anti-bovine Fn IgG diluted 1:500 in 1\% skim milk-PBS, followed by goat anti-rabbit IgG-HRP (diluted 1:6000). Wells incubated with BSA were used as negative control for Fn binding. The bound HRP was detected with 3,3,5,5-tetramethylbenzidine (TMB) solution for 10 min and stopped with $2 \mathrm{M} \mathrm{H}_{2} \mathrm{SO}_{4}$. Absorbance was measured at $630 \mathrm{~nm}$ with a microplate reader. Nonspecific adherence observed in wells without proteins coated was subtracted from all readings. Graphpad Prism version 5 was used to construct graphs.

\subsection{Adherence and Inhibition Assays}

Direct adhesion of rTrmFO to EBL cells was visualized by confocal laser scanning microscopy (CLSM) as described by Zou et al. with some modifications [13]. Briefly, the EBL cells were cultured for $24-36 \mathrm{~h}$ at $37^{\circ} \mathrm{C}$. After washing, EBL cells were fixed with $4 \%$ paraformaldehyde (PFA) at room temperature (RT) for 15 min and then blocked with $1 \%$ donor equine serum in PBS at RT for $1 \mathrm{~h}$. Subsequently, the cells were washed five times with PBST and incubated in $1 \mathrm{~mL}$ of PBS containing $90 \mu \mathrm{g}$ of rTrmFO for $1 \mathrm{~h}$ at $4{ }^{\circ} \mathrm{C}$. For the adherence inhibition assay, the rTrmFO was pre-incubated with $20 \mu \mathrm{L}$ of rabbit anti-rTrmFO serum in $1 \mathrm{~mL}$ of PBS at $4{ }^{\circ} \mathrm{C}$ for $1 \mathrm{~h}$ prior to adding it to the fixed cells. The cells incubated with $1 \mathrm{~mL}$ of PBS without $\mathrm{rTrmFO}$ were used as a negative control. The rTrmFO was used as soon as possible after purification to ensure its biological activity. After excessive washing to remove non-adherent protein, the bound protein was stained with rabbit anti-rTrmFO polyclonal antibodies diluted 1:100 in 1\% equine serum PBS for $1 \mathrm{~h}$, followed by donkey anti-rabbit IgG (whole molecule)-Alexa 488 diluted 1:300 for $1 \mathrm{~h}$. Immunofluorescence was detected using a Carl Zeiss LSM 510 CLSM.

The inhibition of M. bovis adhesion to EBL cells by rabbit anti-rTrmFO serum was performed as previously described with some modifications [38]. Briefly, EBL cells were inoculated into 24-well plates $\left(1.25 \times 10^{5}\right.$ cells/well $)$ and grown to a confluent monolayer. After washing, EBL cells were blocked with $1 \%$ BSA-MEM at $37^{\circ} \mathrm{C}$ for $30 \mathrm{~min}$. Subsequently, EBL cells were infected with M. bovis, which had been pre-incubated with rabbit pre-immune serum or anti-rTrmFO serum for $2 \mathrm{~h}$ at $4{ }^{\circ} \mathrm{C}$, at a multiplicity of infection (MOI) of 1000 for $30 \mathrm{~min}$ at $37^{\circ} \mathrm{C}$. Following four washes with PBS to remove unbound $M$. bovis, EBL cells were liberated with $0.25 \%$ Trypsin in MEM. The bound $M$. bovis were tenfold serially diluted and plated on PPLO agar plates for counting bacterial colonies. Three independent experiments were performed in triplicate. 


\subsection{Statistical Analysis}

Data are expressed as the mean \pm SEM of at least three independent experiments, and the statistical analyses were performed using Student's $t$-test. Significant differences were denoted as ${ }^{*} p<0.05$ and ${ }^{* *} p<0.01$.

Supplementary Materials: Supplementary materials can be found at www.mdpi.com/1422-0067/18/8/1732/s1.

Acknowledgments: This research was supported by National Nature Science Foundation of China (NSFC), grant no. 31302111, 31661143015 and the Fundamental Research Funds for the Central Universities, grant no. 2013QC001. We thank Fei Xue (Harbin Veterinary Research Institute, Chinese Academy of Agricultural Sciences) for offering EBL cells used in this study. We also thank Hanxiong Li for revising our manuscript.

Author Contributions: Yongpeng Guo, Aizhen Guo and Xi Chen conceived and designed the experiments; Yongpeng Guo and Hongmei Zhu performed the experiments; Jiayao Wang and Jing Huang analyzed the data; Farhan Anwar Khan and Jingjing Zhang contributed reagents/materials; Yongpeng Guo and Xi Chen wrote the paper.

Conflicts of Interest: The authors declare no conflict of interest.

\section{References}

1. Pfutzner, H.; Sachse, K. Mycoplasma bovis as an agent of mastitis, pneumonia, arthritis and genital disorders in cattle. Rev. Sci. Tech. 1996, 15, 1477-1494. [CrossRef] [PubMed]

2. Burki, S.; Frey, J.; Pilo, P. Virulence, persistence and dissemination of Mycoplasma bovis. Vet. Microbiol. 2015, 179, 15-22. [CrossRef] [PubMed]

3. Hale, H.H.; Helmboldt, C.F.; Plastridge, W.N.; Stula, E.F. Bovine mastitis caused by a Mycoplasma species. Cornell Vet. 1962, 52, 582-591. [PubMed]

4. Li, Y.; Zheng, H.; Liu, Y.; Jiang, Y.; Xin, J.; Chen, W.; Song, Z. The complete genome sequence of Mycoplasma bovis strain Hubei-1. PLoS ONE 2011, 6, e20999. [CrossRef] [PubMed]

5. Qi, J.; Guo, A.; Cui, P.; Chen, Y.; Mustafa, R.; Ba, X.; Hu, C.; Bai, Z.; Chen, X.; Shi, L.; et al. Comparative geno-plasticity analysis of Mycoplasma bovis HB0801 (Chinese isolate). PLoS ONE 2012, 7, e38239. [CrossRef] [PubMed]

6. Razin, S.; Yogev, D.; Naot, Y. Molecular biology and pathogenicity of Mycoplasmas. Microbiol. Mol. Biol. Rev. 1998, 62, 1094-1156. [PubMed]

7. Rottem, S. Interaction of Mycoplasmas with host cells. Physiol. Rev. 2003, 83, 417-432. [CrossRef] [PubMed]

8. Razin, S.; Jacobs, E. Mycoplasma adhesion. J. Gen. Microbiol. 1992, 138, 407-422. [CrossRef] [PubMed]

9. Sachse, K.; Grajetzki, C.; Rosengarten, R.; Hanel, I.; Heller, M.; Pfutzner, H. Mechanisms and factors involved in Mycoplasma bovis adhesion to host cells. Zent. Bakteriol. 1996, 284, 80-92. [CrossRef]

10. Song, Z.; Li, Y.; Liu, Y.; Xin, J.; Zou, X.; Sun, W. $\alpha$-Enolase, an adhesion-related factor of Mycoplasma bovis. PLoS ONE 2012, 7, e38836. [CrossRef] [PubMed]

11. Zhao, G.; Zhang, H.; Chen, X.; Zhu, X.; Guo, Y.; He, C.; Anwar Khan, F.; Chen, Y.; Hu, C.; Chen, H.; et al. Mycoplasma bovis NADH oxidase functions as both a NADH oxidizing and $\mathrm{O}_{2}$ reducing enzyme and an adhesin. Sci. Rep. 2017, 7, 44. [CrossRef] [PubMed]

12. Sachse, K.; Helbig, J.H.; Lysnyansky, I.; Grajetzki, C.; Muller, W.; Jacobs, E.; Yogev, D. Epitope mapping of immunogenic and adhesive structures in repetitive domains of Mycoplasma bovis variable surface lipoproteins. Infect. Immun. 2000, 68, 680-687. [CrossRef] [PubMed]

13. Zou, X.; Li, Y.; Wang, Y.; Zhou, Y.; Liu, Y.; Xin, J. Molecular cloning and characterization of a surface-localized adhesion protein in Mycoplasma bovis Hubei-1 strain. PLoS ONE 2013, 8, e69644. [CrossRef] [PubMed]

14. Joh, D.; Wann, E.R.; Kreikemeyer, B.; Speziale, P.; Hook, M. Role of fibronectin-binding MSCRAMMS in bacterial adherence and entry into mammalian cells. Matrix Biol. 1999, 18, 211-223. [CrossRef]

15. Henderson, B.; Nair, S.; Pallas, J.; Williams, M.A. Fibronectin: A multidomain host adhesin targeted by bacterial fibronectin-binding proteins. FEMS Microbiol. Rev. 2011, 35, 147-200. [CrossRef] [PubMed]

16. Schwarz-Linek, U.; Hook, M.; Potts, J.R. The molecular basis of fibronectin-mediated bacterial adherence to host cells. Mol. Microbiol. 2004, 52, 631-641. [CrossRef] [PubMed] 
17. Dallo, S.F.; Kannan, T.R.; Blaylock, M.W.; Baseman, J.B. Elongation factor Tu and E1 beta subunit of pyruvate dehydrogenase complex act as fibronectin binding proteins in Mycoplasma pneumoniae. Mol. Microbiol. 2002, 46, 1041-1051. [CrossRef] [PubMed]

18. Grundel, A.; Jacobs, E.; Dumke, R. Interactions of surface-displayed glycolytic enzymes of Mycoplasma pneumoniae with components of the human extracellular matrix. Int. J. Med. Microbiol. 2016, 306, 675-685. [CrossRef] [PubMed]

19. Seymour, L.M.; Jenkins, C.; Deutscher, A.T.; Raymond, B.B.; Padula, M.P.; Tacchi, J.L.; Bogema, D.R.; Eamens, G.J.; Woolley, L.K.; Dixon, N.E.; et al. Mhp182 (P102) binds fibronectin and contributes to the recruitment of plasmin(ogen) to the Mycoplasma hyopneumoniae cell surface. Cell. Microbiol. 2012, 14, 81-94. [CrossRef] [PubMed]

20. Deutscher, A.T.; Jenkins, C.; Minion, F.C.; Seymour, L.M.; Padula, M.P.; Dixon, N.E.; Walker, M.J.; Djordjevic, S.P. Repeat regions R1 and R2 in the P97 paralogue Mhp271 of Mycoplasma hyopneumoniae bind heparin, fibronectin and porcine cilia. Mol. Microbiol. 2010, 78, 444-458. [CrossRef] [PubMed]

21. Bao, S.; Guo, X.; Yu, S.; Ding, J.; Tan, L.; Zhang, F.; Sun, Y.; Qiu, X.; Chen, G.; Ding, C. Mycoplasma synoviae enolase is a plasminogen/fibronectin binding protein. BMC Vet. Res. 2014, 10, 223. [CrossRef] [PubMed]

22. May, M.; Papazisi, L.; Gorton, T.S.; Geary, S.J. Identification of fibronectin-binding proteins in Mycoplasma gallisepticum strain R. Infect. Immun. 2006, 74, 1777-1785. [CrossRef] [PubMed]

23. Zimmermann, L.; Peterhans, E.; Frey, J. RGD motif of lipoprotein T, involved in adhesion of Mycoplasma conjunctivae to lamb synovial tissue cells. J. Bacteriol. 2010, 192, 3773-3779. [CrossRef] [PubMed]

24. Zhang, R.; Han, X.; Chen, Y.; Mustafa, R.; Qi, J.; Chen, X.; Hu, C.; Chen, H.; Guo, A. Attenuated Mycoplasma bovis strains provide protection against virulent infection in calves. Vaccine 2014, 32, 3107-3114. [CrossRef] [PubMed]

25. Urbonavicius, J.; Skouloubris, S.; Myllykallio, H.; Grosjean, H. Identification of a novel gene encoding a flavin-dependent $\mathrm{tRNA}: \mathrm{m}^{5} \mathrm{U}$ methyltransferase in bacteria-Evolutionary implications. Nucleic Acids Res. 2005, 33, 3955-3964. [CrossRef] [PubMed]

26. Robino, P.; Alberti, A.; Pittau, M.; Chessa, B.; Miciletta, M.; Nebbia, P.; Le Grand, D.; Rosati, S. Genetic and antigenic characterization of the surface lipoprotein P48 of Mycoplasma bovis. Vet. Microbiol. 2005, 109, 201-209. [CrossRef] [PubMed]

27. Sun, Z.; Fu, P.; Wei, K.; Zhang, H.; Zhang, Y.; Xu, J.; Jiang, F.; Liu, X.; Xu, W.; Wu, W. Identification of novel immunogenic proteins from Mycoplasma bovis and establishment of an indirect ELISA based on recombinant E1 beta subunit of the pyruvate dehydrogenase complex. PLoS ONE 2014, 9, e88328. [CrossRef] [PubMed]

28. Perez-Casal, J.; Prysliak, T. Detection of antibodies against the Mycoplasma bovis glyceraldehyde-3-phosphate dehydrogenase protein in beef cattle. Microb. Pathog. 2007, 43, 189-197. [CrossRef] [PubMed]

29. Khan, F.A.; Faisal, M.; Chao, J.; Liu, K.; Chen, X.; Zhao, G.; Menghwar, H.; Zhang, H.; Zhu, X.; Rasheed, M.A.; et al. Immunoproteomic identification of MbovP579, a promising diagnostic biomarker for serological detection of Mycoplasma bovis infection. Oncotarget 2016, 7, 39376-39395. [CrossRef] [PubMed]

30. Scherm, B.; Gerlach, G.F.; Runge, M. Analysis of heat shock protein 60 encoding genes of Mycoplasmas and investigations concerning their role in immunity and infection. Vet. Microbiol. 2002, 89, 141-150. [CrossRef]

31. Wawegama, N.K.; Browning, G.F.; Kanci, A.; Marenda, M.S.; Markham, P.F. Development of a recombinant protein-based enzyme-linked immunosorbent assay for diagnosis of Mycoplasma bovis infection in cattle. Clin. Vaccine Immunol. 2014, 21, 196-202. [CrossRef] [PubMed]

32. Prysliak, T.; van der Merwe, J.; Perez-Casal, J. Vaccination with recombinant Mycoplasma bovis GAPDH results in a strong humoral immune response but does not protect feedlot cattle from an experimental challenge with M. bovis. Microb. Pathog. 2013, 55, 1-8. [CrossRef] [PubMed]

33. Kainulainen, V.; Korhonen, T.K. Dancing to another tune-adhesive moonlighting proteins in bacteria. Biology 2014, 3, 178-204. [CrossRef] [PubMed]

34. Henderson, B.; Martin, A. Bacterial virulence in the moonlight: Multitasking bacterial moonlighting proteins are virulence determinants in infectious disease. Infect. Immun. 2011, 79, 3476-3491. [CrossRef] [PubMed]

35. Rahi, A.; Matta, S.K.; Dhiman, A.; Garhyan, J.; Gopalani, M.; Chandra, S.; Bhatnagar, R. Enolase of Mycobacterium tuberculosis is a surface exposed plasminogen binding protein. Biochim. Biophys. Acta 2017, 1861, 3355-3364. [CrossRef] [PubMed] 
36. Bergmann, S.; Rohde, M.; Chhatwal, G.S.; Hammerschmidt, S. $\alpha$-Enolase of Streptococcus pneumoniae is a plasmin(ogen)-binding protein displayed on the bacterial cell surface. Mol. Microbiol. 2001, 40, 1273-1287. [CrossRef] [PubMed]

37. Agarwal, S.; Kulshreshtha, P.; Bambah Mukku, D.; Bhatnagar, R. $\alpha$-Enolase binds to human plasminogen on the surface of Bacillus anthracis. Biochim. Biophys. Acta 2008, 1784, 986-994. [CrossRef] [PubMed]

38. Chen, H.; Yu, S.; Shen, X.; Chen, D.; Qiu, X.; Song, C.; Ding, C. The Mycoplasma gallisepticum $\alpha$-enolase is cell surface-exposed and mediates adherence by binding to chicken plasminogen. Microb. Pathog. 2011, 51, 285-290. [CrossRef] [PubMed]

39. Schreiner, S.A.; Sokoli, A.; Felder, K.M.; Wittenbrink, M.M.; Schwarzenbach, S.; Guhl, B.; Hoelzle, K.; Hoelzle, L.E. The surface-localised $\alpha$-enolase of Mycoplasma suis is an adhesion protein. Vet. Microbiol. 2012, 156, 88-95. [CrossRef] [PubMed]

40. Yavlovich, A.; Rechnitzer, H.; Rottem, S. $\alpha$-Enolase resides on the cell surface of Mycoplasma fermentans and binds plasminogen. Infect. Immun. 2007, 75, 5716-5719. [CrossRef] [PubMed]

41. Muchnik, L.; Adawi, A.; Ohayon, A.; Dotan, S.; Malka, I.; Azriel, S.; Shagan, M.; Portnoi, M.; Kafka, D.; Nahmani, H.; et al. NADH oxidase functions as an adhesin in Streptococcus pneumoniae and elicits a protective immune response in mice. PLoS ONE 2013, 8, e61128. [CrossRef]

42. Adamu, J.Y.; Wawegama, N.K.; Browning, G.F.; Markham, P.F. Membrane proteins of Mycoplasma bovis and their role in pathogenesis. Res. Vet. Sci. 2013, 95, 321-325. [CrossRef] [PubMed]

43. Giron, J.A.; Lange, M.; Baseman, J.B. Adherence, fibronectin binding, and induction of cytoskeleton reorganization in cultured human cells by Mycoplasma penetrans. Infect. Immun. 1996, 64, 197-208. [PubMed]

44. Balasubramanian, S.; Kannan, T.R.; Baseman, J.B. The surface-exposed carboxyl region of Mycoplasma pneumoniae elongation factor Tu interacts with fibronectin. Infect. Immun. 2008, 76, 3116-3123. [CrossRef] [PubMed]

45. Rasheed, M.A.; Qi, J.; Zhu, X.; Chenfei, H.; Menghwar, H.; Khan, F.A.; Zhao, G.; Zubair, M.; Hu, C.; Chen, Y.; et al. Comparative genomics of Mycoplasma bovis strains reveals that decreased virulence with increasing passages might correlate with potential virulence-related factors. Front. Cell. Infect. Microbiol. 2017, 7, 177. [CrossRef] [PubMed]

46. BLASTP. Available online: https:/ / blast.ncbi.nlm.nih.gov/Blast.cgi/ (accessed on 2 March 2017).

47. SignalP. Available online: http:/ / www.cbs.dtu.dk/services/SignalP/ (accessed on 2 March 2017).

48. TMHMM. Available online: http://www.cbs.dtu.dk/services/TMHMM/ (accessed on 2 March 2017).

49. CELLO. Available online: http:/ / cello.life.nctu.edu.tw/ (accessed on 2 March 2017).

50. Alvarez, R.A.; Blaylock, M.W.; Baseman, J.B. Surface localized glyceraldehyde-3-phosphate dehydrogenase of Mycoplasma genitalium binds mucin. Mol. Microbiol. 2003, 48, 1417-1425. [CrossRef] [PubMed]

51. Jenkins, C.; Wilton, J.L.; Minion, F.C.; Falconer, L.; Walker, M.J.; Djordjevic, S.P. Two domains within the Mycoplasma hyopneumoniae cilium adhesin bind heparin. Infect. Immun. 2006, 74, 481-487. [CrossRef] [PubMed]

(C) 2017 by the authors. Licensee MDPI, Basel, Switzerland. This article is an open access article distributed under the terms and conditions of the Creative Commons Attribution (CC BY) license (http://creativecommons.org/licenses/by/4.0/). 